\title{
Anticerebral oedema therapy in Reye's syndrome
}

\author{
F. H. LOVEJOY, Jr., M. J. BRESNAN, C. T. LOMBROSO, and A. L. SMITH \\ From the Departments of Medicine and Neurology, The Children's Hospital Medical Center and the Department \\ of Pediatrics, Harvard Medical School, Boston, Massachusetts
}

\begin{abstract}
Lovejoy, F. H., Jr., Bresnan, M. J., Lombroso, C. T., and Smith, A. L. (1975). Archives of Disease in Childhood, 50,933. Anticerebral oedema therapy in Reye's syndrome. Sixteen patients with Reye's syndrome were seen over a 3-year period and treated with conservative management with an overall mortality of $31 \%$. 6 of the $\mathbf{1 6}$ had illness limited to stages II and III. Intensive therapy of suspected cerebral oedema, with careful monitoring of serum osmolarity, was associated with survival in 5 of 10 patients with stage IV disease. The risks of lumbar puncture in the presence of cerebral oedema (stages III-IV) are emphasized. A change in clinical status (usually a reversal to a less severe stage and an improved electroencephalogram) was seen within hours of starting anticerebral oedema therapy. Neurological sequelae (memory deficit, hemiparesis, hemiballismic movements, and delayed motor milestones) that were present in stage IV survivors at discharge were absent 12 months after discharge. Conservative supportive management emphasizing treatment of presumed cerebral oedema in severe cases of Reye's syndrome has a mortality comparable to that occurring in exchange transfusion or peritoneal dialysis. This form of therapy should be included in controlled trials to determine which form of therapy is optimal.
\end{abstract}

The management of Reye's syndrome has included several therapeutic approaches because of an unclear aetiology and pathogenesis. In addition, the wide spectrum of severity of the illness has made interpretation of various modes of treatment difficult. Therapeutic approaches include exchange transfusion (Huttenlocher, 1972), peritoneal dialysis (Samaha, Blau, and Berardinelli, 1974), insulin and glucose (Brown and Madge, 1971), total body washout (Medical World Nerws, 1972), and treatment as a variant of hepatic encephalopathy (Cohen and Litt, 1972). Because of our previous discouraging results with exchange transfusion (Lovejoy et al., 1974), and because of the brain oedema evident at death, we started a programme of conservative supportive therapy with emphasis on vigorous anticerebral oedema measures. This report describes results in 16 patients studied prospectively from 1971 to 1974 .

\section{Methods}

Our criteria for diagnosis were similar to those found in published reports (Huttenlocher, 1972; Samaha et al., 1974; Lovejoy et al., 1974). (1) A mild antecedent

Received 21 April 1975. illness (upper respiratory infection, gastroenteritis, varicella); (2) objective CNS dysfunction (Lovejoy et al., 1974); (3) hepatic dysfunction manifested by venous ammonia $>50 \mu \mathrm{g} / 100 \mathrm{ml}$ or an increase in serum liver enzyme activity (serum glutamicpyruvic transaminase $>35$ units, serum glutamicoxaloacetic transaminase $>36$ units) and prolonged prothrombin time (prolongation $>3 \mathrm{~s}$ beyond control); (4) exclusion of other disease processes which have similar clinical symptoms (salicylism, drug ingestion, bacterial and viral infections of the central nervous system) through appropriate historical features and laboratory examinations.

Although Reye's syndrome was initially described by its pathological features (fatty infiltration of viscera and cerebral oedema) (Reye, Morgan, and Baral, 1963), it was felt that the above criteria obviated the need for confirmation of the diagnosis by liver biopsy. Increased blood ammonia concentration was not considered to be essential for diagnosis when other indices of hepatic dysfunction existed in association with other criteria. All 5 patients who died had necropsy findings characteristic of Reye's syndrome (Reye et al., 1963).

A system of staging previously described (Lovejoy et al., 1974) was used prospectively to facilitate more accurate assessment of the progression of the disease (Table I). Each patient was given a physical examination with emphasis on neurological findings by one 
TABLE I

\section{Criteria for degree of clinical abnormality}

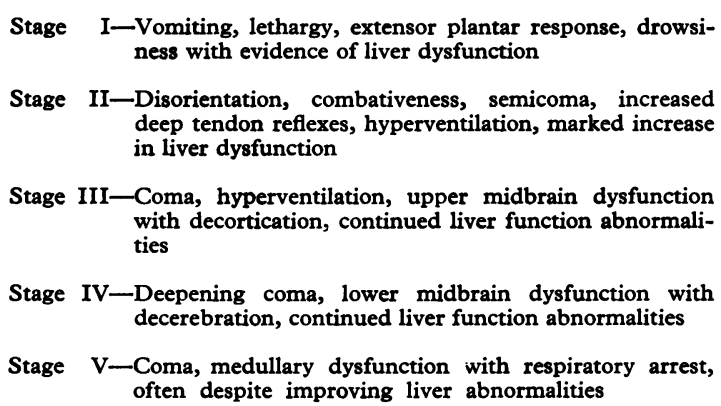

investigator by means of a protocol every 3 to 6 hours throughout the first 7 days in hospital. Electroencephalograms (EEG) were performed on a portable apparatus using previously described techniques (Aoki and Lombroso, 1973) every 8 hours and at the time of a change of clinical stage. EEGs were graded as previously described (Aoki and Lombroso, 1973; Lombroso et al., 1972) and classified into eight groups including normal, borderline, 5 grades of abnormality, and electrocerebral silence. Clinical staging and ammonia determinations were obtained at the time of EEG recordings.

The following therapy was given. (1) Fluid restriction of $40-70 \mathrm{ml} / \mathrm{kg}$ per $\mathrm{d}$, with hourly adjustment of input and output (1) to $\frac{1}{3}$ normal saline with $5 \%$ glucose given intravenously). Adjustments were made to maintain the central venous pressure between 2 and $4 \mathrm{~cm}$ $\mathrm{H}_{2} \mathrm{O}$ while maintaining tissue perfusion as determined by urinary output and muscle $p \mathrm{H}$ (Filler and Das, 1971). Great effort was made to minimize rapid fluctuations in serum osmolarity (osmolarities in stage II patients were maintained between 290 and 310 $\mathrm{mOsm} / \mathrm{l}$, in stage III patients between 310 and 320 , and in stage IV patients between 320 and 330). Serum sodium concentrations were maintained between 145 and $155 \mathrm{mEq} / \mathrm{l}$. (2) Neomycin was given when blood ammonia concentration exceeded $300 \mu \mathrm{g} / 100 \mathrm{ml}$ (neomycin by nasogastric tube $50 \mathrm{mg} / \mathrm{kg}$ per $\mathrm{d}$ and neomycin enemas). (3) Fluid restriction alone in clinical stage II and anticerebral oedema therapy (Shenkin and Bouzarth, 1970) upon entrance into clinical stage III (intravenous dexamethasone $0.5 \mathrm{mg} / \mathrm{kg}$ per d, glycerol 3-6 g/kg per d (per gavage), and frequent administration of intravenous mannitol $0.5-1.5 \mathrm{~g} / \mathrm{kg}$ per dose up to $6 \mathrm{~g} / \mathrm{kg}$ per d with evidence of clinical deterioration). (4) Nasotracheal intubation upon entrance into stage III, maintaining arterial $\mathrm{PCO}_{2}>20$ $\mathrm{mmHg}$ (by the use of dead space or controlled ventilation) and $\mathrm{Po}_{2}>80 \mathrm{mmHg}$. (5) Vitamin $\mathrm{K} 5 \mathrm{mg}$ intravenously daily and transfusion of fresh blood as necessary to maintain the venous haematocrit $>35 \%$. (6) Aluminium and magnesium hydroxide gel (Maalox) by nasogastric tube $(5-10 \mathrm{ml})$ every 2 hours. (7) Treatment of seizures with phenobarbital and diphenylhydantoin.

The severity of disease determined the intensity of anticerebral oedema management with most patients in the same stage receiving identical therapy. Stage IV patients later in the series were more severely fluid restricted and were given anticerebral oedema medications at higher doses more frequently.

\section{Results}

Among 16 patients there were 5 deaths (31\%) (Table II). Of the 11 survivors, 4 progressed to stage II, 2 to stage III, and 5 to stage IV. 2 additional patients had mild disease limited to stage I and are not detailed further. All 6 patients with disease limited to stages II and III recovered without sequelae (Table II). Their average stay in hospital was 5 days, the clinical course was uncomplicated, and there was no evidence of neurological sequelae at discharge. The 5 survivors from stage IV had an average stay in hospital of 24 days (Table III). Neurological sequelae were evident in 2 patients (Cases 7 and 10) at discharge (Table III). 12 months after discharge these sequelae had cleared except for a mild memory deficit and a single generalized convulsion in Case 10 and a mild hemiparesis in Case 7 which continues to improve. Thus, 9 of 11 patients surviving from stages II-IV recovered fully and 2 patients have minimal residual deficits which are still improving.

Neither age nor sex was related to outcome. The mean duration in each stage for those who lived was 45 hours in stage I, 19 hours stage II, 18 hours stage III, and 10 hours stage IV. The mean duration for those who died was 25 hours in stage $I$, 14 hours stage II, 7 hours stage III, 12 hours stage IV, and 26 hours stage V. Thus, those patients who died had a rapidly progressive illness, and remained in clinical stages I-IV for a shorter period of time (total of 58 hours) than those who lived (82 hours).

Seizures occurred in 6 of the 16 patients during stages III and IV. 2 of these 6 patients died, while 2 others had severe but transient neurological sequelae. Decerebrate posturing was present in all 10 patients progressing to stage IV. Decerebration in response to a painful stimulus (sternal rubbing) often preceded the appearence of persistent decerebrate posturing and was considered to be the onset of stage IV. Other midbrain signs found in stage IV (and not found in stages I through III) were abnormal doll's head manoeuvre (ranging from sluggish to absent response) in 9 of 10 patients and an absent ciliospinal reflex in all 
TABLE II

Selected indices in 16 patients with Reye's syndrome

\begin{tabular}{|c|c|c|c|c|c|c|c|c|c|}
\hline \multirow{2}{*}{ Case no. } & \multirow{2}{*}{\multicolumn{2}{|c|}{$\underset{(y \mathbf{r})}{\text { Age }}(\mathbf{m})$}} & \multirow{2}{*}{ Sex } & \multirow{2}{*}{$\begin{array}{l}\text { Furthest } \\
\text { stage of } \\
\text { illness }\end{array}$} & \multicolumn{2}{|c|}{$\mathrm{NH}_{3}(\mu \mathrm{g} / 100 \mathrm{ml})^{\star}$} & \multicolumn{2}{|c|}{ EEG grade } & \multirow{2}{*}{ Outcome } \\
\hline & & & & & Initialt & Highest† & Initial & Worst & \\
\hline $\begin{array}{r}1 \\
2 \\
3 \\
4 \\
5 \\
6 \\
7 \\
8 \\
9 \\
10 \\
11 \\
12 \\
13 \\
14 \\
15 \\
16\end{array}$ & $\begin{array}{r}9 \\
6 \\
7 \\
6 \\
12 \\
10 \\
5 \\
8 \\
11 \\
14 \\
13 \\
6 \\
5 \\
6 \\
4 \\
6\end{array}$ & $\begin{array}{r}9 \\
2 \\
2 \\
6 \\
2 \\
8 \\
6 \\
7 \\
7 \\
1 \\
1 \\
2 \\
6 \\
10 \\
0\end{array}$ & $\begin{array}{l}\mathbf{F} \\
\mathbf{F} \\
\mathbf{F} \\
\mathbf{F} \\
\mathbf{F} \\
\mathbf{F} \\
\mathbf{M} \\
\mathbf{M} \\
\mathbf{F} \\
\mathbf{M} \\
\mathbf{M} \\
\mathbf{F} \\
\mathbf{M} \\
\mathbf{F} \\
\mathbf{M}\end{array}$ & $\begin{array}{l}\text { II } \\
\text { II } \\
\text { II } \\
\text { II } \\
\text { III } \\
\text { III } \\
\text { IV } \\
\text { IV } \\
\text { IV } \\
\text { IV } \\
\text { IV } \\
\text { V } \\
\text { V } \\
\text { V } \\
\text { V } \\
\text { V }\end{array}$ & $\begin{array}{l}100 \text { (II) } \\
74 \text { (II) } \\
18 \text { (II) } \\
45 \text { (II) } \\
61 \text { (II) } \\
98 \text { (III) } \\
114 \text { (III) } \\
108 \text { (III) } \\
81 \text { (II) } \\
172 \text { (III) } \\
16 \text { (II) } \\
245 \text { (II) } \\
1221 \text { (IV) } \\
145 \text { (II) } \\
285 \text { (III) } \\
600 \text { (II) }\end{array}$ & $\begin{array}{l}100 \text { (II) } \\
74 \text { (II) } \\
18 \text { (II) } \\
67 \text { (II) } \\
61 \text { (II) } \\
234 \text { (III) } \\
114 \text { (III) } \\
183 \text { (III) } \\
148 \text { (III) } \\
211 \text { (IV) } \\
16 \text { (II) } \\
401 \text { (II) } \\
1221 \text { (IV) } \\
1762 \text { (V) } \\
285 \text { (III) } \\
1390 \text { (III) }\end{array}$ & $\begin{array}{c}3 \\
2 \\
3 \\
3 \\
3 \\
2 \\
3 / 4 \ddagger \\
3 \\
3 / 4 \ddagger \\
4 \\
3 \\
3 \\
5 \\
2 \\
3 \\
4\end{array}$ & $\begin{array}{c}3 \\
2 \\
3 \\
3 \\
3 \\
3 \\
3 / 4 \ddagger \\
3 \\
3 / 4 \ddagger \\
4 \\
3 \\
4 \\
5 \\
5 \\
5 \\
5\end{array}$ & $\begin{array}{l}\text { Lived } \\
\text { Lived } \\
\text { Lived } \\
\text { Lived } \\
\text { Lived } \\
\text { Lived } \\
\text { Lived } \\
\text { Lived } \\
\text { Lived } \\
\text { Lived } \\
\text { Lived } \\
\text { Died } \\
\text { Died } \\
\text { Died } \\
\text { Died } \\
\text { Died }\end{array}$ \\
\hline
\end{tabular}

* Normal, $<50 \mu \mathrm{g} / 100 \mathrm{ml}$ (venous blood); + stage at determination in parentheses; $¥$ EEGs were mainly grade 3 with elements of grade 4 ; $\S$ transferred 72 hours after onset of coma.

Note: All patients had raised liver enzyme (serum glutamic-pyruvic transaminase, serum glutamic-oxaloacetic transaminase).

TABLE III

Morbidity in 5 stage IV survivors

\begin{tabular}{|c|c|c|c|c|}
\hline Case no. & $\begin{array}{c}\text { Days of } \\
\text { hospitalization }\end{array}$ & Complications & Sequelae at discharge & $\begin{array}{l}\text { Sequelae at } 12 \mathrm{~m} \\
\text { after discharge }\end{array}$ \\
\hline 7 & 29 & $\begin{array}{l}\text { Internal bleeding, drug } \\
\text { rash }\end{array}$ & $\begin{array}{l}\text { Bilateral paresis with right- } \\
\text { sided hemiballismic } \\
\text { movements responsive to } \\
\text { haloperidol }\end{array}$ & $\begin{array}{l}\text { Minimal hemiparesis on } \\
\text { left; mentally normal }\end{array}$ \\
\hline 8 & 14 & $\begin{array}{l}\text { Right upper lobe atelectasis } \\
\text { after ventilatory support }\end{array}$ & $\begin{array}{l}\text { Motor milestones delayed } \\
\text { at discharge }\end{array}$ & $\begin{array}{l}\text { Normal by } 2 \mathrm{w} \text { after } \\
\text { discharge }\end{array}$ \\
\hline 10 & 54 & $\begin{array}{l}\text { Massive internal bleeding } \\
\text { with subtotal gastrectomy, } \\
\text { pneumonia with } \\
\text { empyemra, subphrenic } \\
\text { abscess }\end{array}$ & $\begin{array}{l}\text { Marked left hemiparesis, } \\
\text { transient hemiparesis on } \\
\text { right; severe short- and } \\
\text { long-term memory deficit }\end{array}$ & $\begin{array}{l}\text { Minimal short-term } \\
\text { memory deficit without } \\
\text { evidence of hemiparesis; } \\
\text { one generalized seizure } \\
5 \mathrm{~m} \text { after discharge }\end{array}$ \\
\hline 11 & 15 & $\begin{array}{l}\text { Subglottic stenosis } \\
\text { (secondary to intubation) } \\
\text { requiring tracheotomy }\end{array}$ & None & None \\
\hline
\end{tabular}

9 patients tested in stage IV. In all but one patient the pupillary reflex was present until the onset of stage V. The pupils were maximally dilated in stages II through IV. In stage V they were small and fixed and then later became dilated and fixed.

EEGs reflected the severity of a patient's illness and a change in EEG often preceded a change in clinical stage. 10 of 13 patients with an EEG of grade 3 or better on admission survived, while 2 of the 3 with grade 4 or worse died. The one survivor with a grade 4 EEG on admission lived but had neurological sequelae (case 10). Of the 10 survivors with a grade 3 EEG or better on admission, one had neurological sequelae (Case 7). Cases 9 and 11 had elements of grade 4 in their admitting EEGs but rapidly reverted to grade 3 within 12 to 18 hours of admission. The EEG was of prognostic significance in one patient (Case 16) who presented in clinical stage II with EEG grade 4 (also blood ammonia of $600 \mu \mathrm{g} / 100 \mathrm{ml}$ on admission) and eventually died.

When the 10 patients who reached stage IV are considered, those receiving more intensive therapy to combat cerebral oedema (mannitol in doses up 
to $6 \mathrm{~g} / \mathrm{kg}$ per d, glycerol up to $6 \mathrm{~g} / \mathrm{kg}$ per d, dexamethasone at $0.5 \mathrm{mg} / \mathrm{kg}$ per d, and fluid restriction to $40 \mathrm{ml} / \mathrm{kg}$ per d) had a higher survival rate, 4 of 6 , in contrast to death occurring in 3 of 4 who were treated with conventional anticerebral oedema therapy (fluid restriction to approximately 60 $\mathrm{ml} / \mathrm{kg}$ per d, dexamethasone at $0.5 \mathrm{mg} / \mathrm{kg}$ per d, and either sporadic use of or no glycerol and mannitol). Clinical findings (usually a reversal to an improved stage and EEG grade) improved within hours of vigorous therapy.

\section{Discussion}

A previously described system of staging (Lovejoy et al., 1974; Aoki and Lombroso, 1973) proved valuable in grading the severity of disease, in following the rate of its progression, and in assessing the effect of a particular form of therapy. It has also allowed comparison among different series of patients as to relative severity of illness and efficacy of different types of therapy. Improvement in clinical stage was seen with vigorous anticerebral oedema measures started in response to neurological deterioration.

Cerebral oedema seemed important as an aetiological factor in causing neurological deterioration because of previous observations of increased CSF pressure in stages III and IV with poor prognosis (Lovejoy et al., 1974), the presence of cerebral oedema at necropsy, and the rapid reversal of neurological deterioration with vigorous anticerebral oedema therapy. These findings, coupled with our impression of clinical worsening after lumbar puncture and warnings as to the dangers of lumbar puncture in the face of diffusely increased intracranial pressure (Byers, 1973) led us to attempt to diagnose Reye's syndrome by clinical and laboratory data and to avoid lumbar puncture if possible.

Maintenance of a low central venous pressure (2-4 $\mathrm{mm} \mathrm{H}_{2} \mathrm{O}$ ) and prevention of rapid fluctuations in raised osmolarities (stage III and stage IV ranging from 310 to 330 ) (Lovejoy et al., 1974) while maintaining adequate renal and tissue perfusion (maintenance of muscle $\mathrm{pH}>7 \cdot 4$ and assurance of adequate urinary output) appeared to be critical in preventing cerebral oedema. Maintenance of the arterial $\mathrm{Po}_{2}$ between $80-120 \mathrm{mmHg}$ and correction of the metabolic acidosis by adjustment of arterial $\mathrm{pH}$ to normal range are part of sound supportive management.

The magnitude of the rise in ammonia level, the rate of its progression through the stages, and a worsening of the EEG grade continue to suggest a poor outcome (Lovejoy et al., 1974; Aoki and Lombroso, 1973; Lombroso et al., 1972; Hutten- locher, Schwartz, and Klatskin, 1969). Hypoglycaemia (blood glucose $<50 \mathrm{mg} / 100 \mathrm{ml}$ ) occurred in 2 patients, both of whom were under 5 years of age. Blood ammonia, as noted previously, correlated with eventual outcome (Table II) (Lovejoy et al., 1974). Except for Case 14, the highest venous blood ammonia concentration occurred on the first or second day in hospital. The mean maximum blood ammonia concentration observed during the patient's course was $111 \mu \mathrm{g} / 100 \mathrm{ml}(\mathrm{n}=11)$ in the surviving group compared to $1012 \mu \mathrm{g} / 100 \mathrm{ml}$ $(n=5)$ in the group not surviving $(P<0 \cdot 01)$. There were no survivors with an initial blood ammonia concentration $>300 \mu \mathrm{g} / 100 \mathrm{ml}$, while of 14 patients with an initial blood ammonia concentration $<300 \mu \mathrm{g} / 100 \mathrm{ml} 11$ survived $(80 \%)$. When blood ammonia concentrations are considered at any time during stay in hospital, all 4 patients with concentrations above $300 \mu \mathrm{g} / 100 \mathrm{ml}$ died, while 11 of 12 with a concentration below $300 \mu \mathrm{g}$ lived $(P<0.01)$. Case 3 had a normal blood ammonia concentration but had clear evidence of stage II disease. Case 11 was transferred from another hospital after 72 hours of coma with no prior determination of blood ammonia concentration. Experience has suggested that the increased blood ammonia concentration often returns to normal by 72 hours (Huttenlocher, 1972; Lovejoy et al., 1974). Serum aspartate and serum alanine aminotransferase, and lactic dehydrogenase values, and prothrombin time determinations were not predictive for outcome and correlated poorly with severity of illness. A rapid rate of progression through stages (especially stages I-III) suggested a poor outcome. Seizures occurred in the more severely ill patients (usually those in stages III and IV) but were not of prognostic significance. A worsening in EEG grade often preceded a worsening in clinical stage. An EEG at any time in the illness worse than grade 3 indicated a poor prognosis, there being only one such survivor.

Mortality figures for this disease in 1968 were as high as $83 \%$ (Randolph and Gelfman, 1968). Our previous experience between 1968 and 1971 showed a wide spectrum of disease ranging from a mild asymptomatic sib of the index cases with minimal liver function abnormalities, to rapidly progressive fulminant disease unresponsive to any form of therapy (Lovejoy et al., 1974). At that time there was $27 \%$ mortality with supportive therapy alone, while a more severely ill group of patients treated with exchange transfusion had a mortality of $70 \%$ (Lovejoy et al., 1974). The overall mortality was $47 \%$ and there were only 2 survivors from clinical stage IV, both of whom 
TABLE IV

Outcome related to therapy and stage in which therapy was given

\begin{tabular}{|c|c|c|c|c|c|}
\hline \multirow{2}{*}{ Institution/therapy } & \multirow{2}{*}{$\begin{array}{l}\text { Overall } \\
\text { mortality }\end{array}$} & \multicolumn{4}{|c|}{ Survival } \\
\hline & & Stage II & Stage III & Stage IV & Stage V \\
\hline $\begin{array}{l}\text { Boston (conservative anticerebral oedema) } \\
\text { Yale (exchange transfusion) } \\
\text { (Huttenlocher, 1972) } \\
\text { Boston (exchange transfusion) } \\
\text { (Lovejoy et al., 1974) } \\
\text { Pittsburgh (dialysis) (Samaha et al.. 1974) } \neq\end{array}$ & $\begin{array}{c}5 / 16(31 \%) \\
2 / 7(29 \%) \\
10 / 14(71 \%) \\
2 / 11(18 \%)\end{array}$ & $\begin{array}{l}4 / 4 \\
0 \\
1 / 4 \\
1 / 1\end{array}$ & $\begin{array}{l}2 / 2 \\
2 / 2 \\
3 / 3+ \\
5 / 5\end{array}$ & $\begin{array}{l}5 / 10 \\
3 / 3 \\
0 / 5 \\
3 / 3\end{array}$ & $\begin{array}{l}0 / 5 \\
0 / 2 \\
0 / 2 \\
0 / 2\end{array}$ \\
\hline
\end{tabular}

* Includes 4 patients with no exchange transfusion; † one patient progressed to stage IV and survived with permanent severe CNS sequelae ₹ subsequently 9 of 11 dialysed patients died ( $80 \%$ mortality) (Medical World News, 1972; $\mathcal{F} A M A, 1974$ ).

were nonfunctioning individuals. In 1972, Huttenlocher reported a mortality rate of $28.5 \%$ ( 5 of 7 surviving with exchange transfusion). Recently Samaha et al. (1974) reported a mortality of $18 \%$ with peritoneal dialysis. Both forms of therapy appeared to contribute to survival from clinical stage IV.

The present series, using conservative management combined with vigorous anticerebral oedema therapy, gave an overall mortality rate of $31 \%$ with recovery from stage IV in 5 of 10 patients. Further, the series showed the high likelihood of full recovery from neurological sequelae with 3 of 5 stage IV survivors being neurologically normal at discharge and 2 showing minimal impairment (Cases 7 and 10). The deficits in Cases 7 and 10 (Table III) have been interpreted as vascular accidents. It is not known whether these were related to cerebral oedema with uncal herniation or a consequence of extreme therapeutic dehydration.

Survival now occurs from stage IV disease with three forms of therapy: conservative management with vigorous anticerebral oedema therapy, exchange transfusion, and peritoneal dialysis. Overall mortality of $31 \%$ (5 of 16), $29 \%$ ( 2 of 7 ), and $18 \%$ ( 2 of 11 ) have been reported (Table IV). More recent figures concerning peritoneal dialysis are discouraging (9 of 11 died, $80 \%$ mortality) (Medical World News, 1972; JAMA, 1974). Because numbers of patients undergoing each type of therapy remain small and because survival from stage IV is critical, a controlled co-operative multicentre study seems to be necessary to determine which form of therapy is optimal (Redeker and Yamahiro, 1973; Nadler, 1974).

\section{REFERENCES}

Aoki, Y., and Lombroso, C. T. (1973). Prognostic value of electroencephalography in Reye's syndrome. Neurology, 23, 333.
Brown, R. E., and Madge, G. E. (1971). Therapeutic considerations in Reye's syndrome. Pediatrics, 48, 162.

Byers, R. K. (1973). To tap or not to tap. Pediatrics, 51, 561.

Cohen, M., and Litt, I. (1972). Evaluation of the management o hepatic encephalopathy. Fournal of Pediatrics, 80, 851.

Filler, R. M., and Das, J. B. (1971). Muscle surface pH: a new parameter in the monitoring of the critically ill child. Pediatrics, 47,880 .

Huttenlocher, P. R. (1972). Reye's syndrome: relation of outcome to therapy. Fournal of Pediatrics, 80, 845.

Huttenlocher, P. R., Schwartz, A. D., and Klatskin, C. (1969). Reye's syndrome: ammonia intoxication as a possible factor in the encephalopathy. Pediatrics, 43, 443.

Fournal of the American Medical Association (1974). Various regimens produce spotty results against Reye syndrome, 228, 9.

Lombroso, C. T., Bresnan, M., Aoki, Y., Lovejoy, F. H., and Smith, A. L. (1972). Prognostic criteria in Reye's syndrome. Transactions of the American Neurological Association, 97, 303.

Loveioy, F. H., Jr., Smith, A., Bresnan, M., Wood, J. N., Victor, D. I., and Adams, P. C. (1974). Clinical staging in Reye's syndrome. American fournal of Diseases of Children, 128, 36.

Medical World News (1972). Total body washout-safer surgery, $13,19$.

Nadler, H. (1974). Therapeutic delirium in Reye's syndrome. Pediatrics, 54, 265.

Randolph, M., and Gelfman, N. A. (1968). Acute encephalopathy in children associated with acute hepatocellular dysfunction. American fournal of Diseases of Children, 116, 303.

Redeker, A. G., and Yamahiro, H. S. (1973). Controlled trial of exchange-transfusion therapy in fulminant hepatitis. Lancet, $1,3$.

Reye, R. D. K., Morgan, G., and Baral, J. (1963). Encephalopathy and fatty degeneration of the viscera, a disease entity in childhood. Lancet, 2, 749.

Samaha, F., Blau, E., and Berardinelli, J. (1974). Reye's syndrome: clinical diagnostic and treatment with peritoneal dialysis. Pediatrics, 53, 336.

Shenkin, H. A., and Bouzarth, W. F. (1970). Clinical methods of reducing intracranial pressure. New England fournal of Medicine, 282, 1465.

Supported by a grant (RR-128) from the General Clinical Research Centers Program of the Division of Research Resources, National Institutes of Health and supported in part by NINDS Grant no. 5 PO1 NS0970403 NSPA.

Correspondence to Dr. F. H. Lovejoy, Children's Hospital Medical Center, 300 Longwood Avenue, Boston, Massachusetts 02115, U.S.A. 